\title{
Analysis of Lesson Plans from Rwandan Physics Teachers
}

\author{
Kizito Ndihokubwayo* \\ African Center of Excellence for Innovative Teaching and Learning of \\ Mathematics and Science (ACEITLMS) \\ University of Rwanda College of Education (URCE), Rwanda \\ https://orcid.org/0000-0002-2566-8045 \\ Irénée Ndayambaje \\ Rwanda Education Board (REB), Rwanda \\ https://orcid.org/0000-0002-5300-9063 \\ Jean Uwamahoro \\ African Center of Excellence for Innovative Teaching and Learning of \\ Mathematics and Science (ACEITLMS) \\ University of Rwanda College of Education (URCE), Rwanda \\ https://orcid.org/0000-0002-1730-6685
}

\begin{abstract}
Lesson planning is a crucial roadmap guiding the teacher before the implementation of the lesson. In the current study, we aimed at reviewing pedagogical documents used by Rwandan physics teachers. We gathered 32 lesson plans related to optics topics from five teachers and analyzed them using the lesson plan analysis protocol (LPAP) and lesson plan evaluation form (LPEF) jointly. We have found that teachers do not prepare these documents as required by the newly introduced competence-based curriculum. Teachers plan for low levels of Bloom's cognitive and affective taxonomy domains and do not follow effective inquiry techniques along the stages of the lesson activities. A detailed discussion on each teacher's practice was provided, and we hope it can serve as a qualitative overview on teaching and learning planning for effective classroom implementation. Due to the importance of pedagogical documents on effective teaching, we went through a rigorous validation process and suggested a model lesson plan to be consulted by any physics teacher (please see Appendix C). We recommend that teachers consult this lesson plan and prepare accordingly before class.
\end{abstract}

Keywords: pedagogical document; lesson plan; physics teacher; competence-based curriculum

\footnotetext{
*Corresponding author: Kizito Ndihokubwayo; Email: ndihokubwayokizito@gmail.com
} 


\section{Introduction}

Any teacher in any subject needs to prepare the lesson before implementing it in the classroom. There are many types of pedagogical documents that teachers need as their daily instruments. These include the scheme of work, lesson plan, class diary, mark sheet, attendance list, notebook, evaluation notebook, exercise notebook, and so forth. However, these documents are importantly used for different purposes according to different teachers and education systems across the world. A system of training teachers in the Rwandan education system date back to colonialism around the 1900s, when formal education was introduced. Before competence-based curriculum (CBC), the knowledge-based curriculum $(\mathrm{KBC})$ also emphasized much on effective PDs. However, the current CBC (REB, $2015 \mathrm{~b}$ ) focuses on learner-centered as one of the millennium development goals implemented in 2000 (Abbott, Sapsford \& Rwirahira, 2015; Nsengimana et al., 2020). As of 2016, all teachers were required to shift from knowledge-based approaches and adapt to competence-based approaches. Except for content knowledge, others related to pedagogical knowledge, instructional tool, and methods have all shifted towards learner engagement related approaches, including the ways of preparing PDs.

Pedagogical documents are essential because they guide teachers to the expected destination. For instance, the work (SW) scheme guides teachers in a whole year or term (REB, 2015c). SW focuses on unit planning, while lesson plan (LP) focuses on topic planning (REB, 2015a). SW consists of what a teacher will teach in a term. It is a well-scheduled document in the form of a bunch of lessons, while an LP is a sheet of paper showing what the teacher will follow during a class of one or two periods (REB, 2017). Jacobs, Martin, and Otieno (2008) refer to a lesson plan to a teacher's day-to-day teaching practice focusing on pedagogical knowledge. PDs are vital because they guide teachers' daily work. The scheme of work should be well prepared to guide the teacher to schedule the lesson for an extended time frame, while a lesson plan should be well prepared to reflect what will be done in a real classroom. An investigation carried out in Rwanda during learning optics showed the low performance and conceptual understanding of geometric optics (Ndihokubwayo, Uwamahoro \& Ndayambaje, 2020a) and physical optics (Ndihokubwayo et al., 2020). Therefore, we were interested in analyzing these documents used by some physics teachers to check the way teachers prepare their PDs, mainly LPs. Planning is key for any teacher for his/her professional development (Ruys, van Keer \& Aelterman, 2012). Pramoolsook and Magday (2019) and Sawyer and Myers (2018) assume that a lesson plan is a precise reflection of what arises in the classroom. Thus, a link between teacher's planning and students' outcome should arise. This study will help teachers to value the preparation before the class takes place using various LP tools. Teachers generally prepare the lesson plans for evaluation purposes by school administrators (Causton-Theoharis, Theoharis \& Trezek, 2008; Sawyer \& Myers, 2018; Theoharis \& Causton-Theoharis, 2011), such as monitoring classroom curriculum implementation. However, they can serve as a roadmap to teachers for effective classroom implementation. They can also ensure that lesson plans are available and clear for substitutes in case the teacher is absent (Jacobs et al., 2008). The LPs include references to page numbers to be covered in the textbook, problems to be assigned as homework, and lists of standards or objectives to be covered during the lesson delivery. 
The use of both lesson plan analysis protocol (LPAP) and lesson plan evaluation form (LPEF) is limited to LP only. Therefore, classroom observation should serve as a supplement to obtain data about the program under investigation. The lesson plan tools are used to prescribe the components of a program in terms of established models quantitatively and help determine the program's level of implementation (Boikhutso, 2010; Pramoolsook \& Magday, 2019). A lesson plan analysis tool is a scalable and broader lens to support other tools that measure teaching behavior, such as classroom observation. However, it does not show evidence about lesson enactment until post-lesson information is delivered (Diem \& Thathong, 2019; Jacobs et al., 2008).

\subsection{Research problem}

It is essential to check what was planned before observation. The literature shows a strong relationship between teacher planning and student outcomes, as it is assumed that the teacher's lesson plan reflects the classroom activity (JICA, 2020). Therefore, LPs would be useful in program evaluation, such as tracking CBC implementation and teacher assessment. The SIIQS' project initiated lesson plan analysis through lesson study activity in Rwanda; however, there have been no studies evaluated of lesson plans for the physics CBC. Consecutive studies done in Rwanda found gaps both in pedagogical document preparation and classroom teaching practices. For instance, Byusa, Kampire, and Mwesigye (2020) found that the teachers do not take the PDs as their guide; instead, they only care about presenting them to education authorities such as district education officers, headteachers, or deputy headteacher in charge of studies. Ndihokubwayo, Uwamahoro and Ndayambaje (2020b) observed 42 physics classes using the RTOP tool and found that reformed teaching is $53 \%$ and teachers are running out of time and do not care about inquiry instruction. Nowadays, the inquiry is gradually receiving considerable room in many developing countries' science curriculum though it is at its early stage in Rwanda (Mugabo, 2012).

\subsection{Research questions}

This study aims at reviewing Rwandan physics teachers' lesson plans in line with the following research questions:

i) To what extent do physics teachers' lesson plans reflect on a competence-based curriculum?

ii) How do physics teachers prepare their lesson plans based on cognitive and practical Bloom Taxonomy's domains?

iii) Do physics teachers introduce inquiry-based planned instruction in their lesson plans?

This study bridges the gap between teacher lesson preparation and real classroom practices. It shows teachers an effective way of lesson planning. Therefore, we hypothesize that there will be no difference among teachers in terms of lesson preparation. This research's novelty is that we designed and validated a model lesson plan that any teacher can refer to.

\footnotetext{
${ }^{\dagger}$ SIIQS: Project for Supporting Institutionalizing and Improving the Quality of School-Based Inservice Teacher Training Activity
} 


\section{Methods and Procedures}

This is basic and applied research (Orodho et al., 2016). It is basic in a way that it adds knowledge of Rwandan physics teachers' lesson planning to existing literature while is applied in a way that we have designed a model lesson plan for teachers' references. We have used a mixed methodology to present the data. Thus, we have documented the characteristics of the lesson plans and discussed the variability among teachers.

\subsection{Sample scope}

To carry out this study, we got an ethical clearance from the research and innovation unit at the University of Rwanda College of Education (URCE) for and research permission from distinguished districts. We, in May 2019, have visited two schools in Kigali and the Eastern province, Rwanda. Our sample targeted 11 physics teachers from four districts in Rwanda selected purposively from schools accommodating advanced level-grade 10 and 11 -science, including physics subject. We invited them to share with us the taught lesson plans related to optics. These LPs should have been used in the last term (from middle January and early April 2019). Eight teachers shared with us their lesson plans in hand or online. Three of eight teachers shared the LPs that are not relevant. One teacher shared mathematics LPs; two teachers shared LPs of mechanics related topics such as "Kinematics and simple harmonic motion," "Simple harmonic oscillation (Simple pendulum)," "Simple harmonic oscillator (Mass suspended from a coiled spring)" and "Representation, characteristics, and properties of sounds waves." Among these two teachers, one shared LPs related to optics but from 2018. We did not consider all of these LPs from three teachers for our analysis. Thus, our analysis took a case of five physics teachers' lesson plans. We have collected 32 LPs, representing approximately $54 \%$ of the sampled teachers (Appendix A).

\subsection{Data sources}

We used two necessary LP analysis tools to carry out this study. The LPAP of Ndihokubwayo et al. (2020) and the LPEF of Ferrell (1992). LPAP analyses nine elements of a competence-based lesson plan. These 9 LPAP elements consist 27 items (Ndihokubway et al., 2020). The nine elements are sub-sectioned into three stages: preliminary elements, the body of the content, and the accessories. "A Lesson Plan Evaluation Form (LPEF) was developed to provide systematic quantitative data about classroom functioning (Ferrel 1992, p. 23)." The LPEF involves three models-curriculum, Bloom Taxonomy domains, and inquiry techniques - of learning used in developing a curriculum where each lesson plan is scrutinized to determine the level to which it reflected the discerned curriculum elements (Ferrell, 1992). The developer of LPEF used the Inquiry Model to weigh the degree to which the LPs reflected a chance to gather and organize data and formulate and test hypotheses. The LPAP components align with LP format for a competence-based curriculum (REB, 2019) while LPEF calls upon the inquirybased physics instruction (Ferrell, 1992) and illuminates the outcome from teacher planned teaching practices.

\subsection{Reliability analysis}

In analyzing these $32 \mathrm{LPs}$, we read all the documents and classified them according to the reserved scales (see Table 1). We used SPSS version 23.0 to analyze both reliability tests and data presented in the results section. 
Table 1: LPAP scales (Ndihokubwayo et al., 2020)

\begin{tabular}{|c|c|c|c|c|c|}
\hline & Explanation & Scale 1 & Scale 2 & Scale 3 & Scale 4 \\
\hline Item1 & $\begin{array}{l}\text { Related to Key Unit Competence } \\
\text { (KUC) }\end{array}$ & Not written & $\begin{array}{l}\text { Written but not related to } \\
\text { syllabus }\end{array}$ & $\begin{array}{l}\text { Written in summary and related } \\
\text { to syllabus }\end{array}$ & Written in full and related to syllabus \\
\hline Item2 & $\begin{array}{l}\text { Related to the format of the lesson } \\
\text { title }\end{array}$ & More than three & Triple & Double title & Single title \\
\hline Item3-4 & $\begin{array}{l}\text { Relationship between lesson title } \\
\text { and time, and the connection to } \\
\text { the syllabus }\end{array}$ & & Probably not & Probably yes & Definitely yes \\
\hline Item5 & $\begin{array}{l}\text { Related to Instructional Objective } \\
\text { (IO) }\end{array}$ & Not written & $\begin{array}{l}\text { Written but Not related to } \\
\text { the topic }\end{array}$ & Written and related to the topic & $\begin{array}{l}\text { Written and related to the topic and } \\
\text { content }\end{array}$ \\
\hline Item6 & Number of IO components & None & One to two & Three to four & All five \\
\hline Item7 & $\begin{array}{l}\text { Related to Special Education } \\
\text { Needs (SEN) }\end{array}$ & Not written & $\begin{array}{l}\text { "none" or "-" or the teacher } \\
\text { writes a number only }\end{array}$ & Describe only & Write the number and describe \\
\hline Item8 & Addressing SEN & Not addressed & $\begin{array}{l}\text { Not clear where it was } \\
\text { addressed }\end{array}$ & $\begin{array}{l}\text { Addressed in } \mathrm{IO} \text { or Description } \\
\text { of Teaching and Learning } \\
\text { Activity (DTLA) }\end{array}$ & $\begin{array}{l}\text { Addressed in Introduction to the lesson } \\
\text { (Intro), or Lesson development (Dev), or } \\
\text { Conclusion of the lesson (Concl)) }\end{array}$ \\
\hline Item9 & Related to DTLA & Not written & Written but not related & $\begin{array}{l}\text { Written but does not show well } \\
\text { what will be done in the lesson }\end{array}$ & $\begin{array}{l}\text { Written and shows well what will be done } \\
\text { in the lesson }\end{array}$ \\
\hline Item10-12 & Writing the content of the lesson & Not written & $\begin{array}{l}\text { Written but unclear (or not } \\
\text { related) }\end{array}$ & Written but not describe (outline) & Written and well described \\
\hline Item13-14 & $\begin{array}{l}\text { Stages of the development and } \\
\text { conclusion sections }\end{array}$ & $\begin{array}{l}\text { Components } \\
\text { outlined in "Note" } \\
\text { are absent }\end{array}$ & Not clear/not identifiable & $\begin{array}{l}\text { Other components apart from } \\
\text { those outlined in "Note." }\end{array}$ & $\begin{array}{l}\text { Components outlined in "Note" are } \\
\text { present }\end{array}$ \\
\hline Item15-23 & $\begin{array}{l}\text { Teaching resources (TR), } \\
\text { Formative assessment (FA), } \\
\text { Active learning techniques } \\
\text { (ALT)in the content of the lesson }\end{array}$ & Not visualized & Visualized but not clear & $\begin{array}{l}\text { At least one is visualized and } \\
\text { clear }\end{array}$ & More than one is visualized and clear \\
\hline Item24 & $\begin{array}{l}\text { If visualized, was the ALT used } \\
\text { with purpose? }\end{array}$ & Definitely not & Probably not & Probably yes & Definitely yes \\
\hline Item25-26 & $\begin{array}{l}\text { Generic competences (GCs) and } \\
\text { Cross-cutting issues (CCIs) }\end{array}$ & Not written & Not clear & Outlined only & Outlined and described \\
\hline Item27 & Teacher self-evaluation (TSE) & Not written & Written but not clear & $\begin{array}{l}\text { The teacher writes a simple word } \\
\text { "well or not well done" }\end{array}$ & $\begin{array}{l}\text { The teacher well describes with the next } \\
\text { step }\end{array}$ \\
\hline
\end{tabular}


The criterion validity check has shown that the data from the LPAP were consistent with data from other more standardized evaluation tools such as Lesson Plan Evaluation Form (LPEF) and Science Lesson Plan Analysis Instrument (SLPAI). A positive correlation (Pearson product-moment coefficient $r>.50)$ was detected across "Lesson approaches" of LPAP, "Inquiry techniques" of LPEF, and "Student inquiry" of the SLPAI items.

Each lesson plan was assigned a number and separately rated by two raters from the African Center of Excellence for Innovative Teaching and Learning of Mathematics and Science (ACEITLMS) based at the University of Rwanda College of Education (URCE); among them, one is the first author of this study. These raters are experienced in analyzing lesson plans and are familiar with the LPAP.

The Spearman's rho among the raters was computed and found to be .81 , while the weighted kappa was found to be .72 across 27 LPAP items. Thus, the raters did not differ in the way in which they rated the lesson plans.

The preliminaries (item1-9) got a reliability coefficient of .92 (and a weighted Kappa of .87) across 32 LPs averaged from two raters. The body of the content (item 10-24) got a reliability coefficient of .79 (and a weighted Kappa of .69), while the accessories (item 25-27) got .58 (and a weighted Kappa of .48). Table 2 presents detailed interrater reliability among 9 LPAP elements.

Table 2: Interrater reliability statistics across LPAP elements

\begin{tabular}{lll}
\hline LPAP elements & Spearman's rho & $\begin{array}{l}\text { Weighted } \\
(\mathbf{K})\end{array}$ \\
\hline Key unit competence & 0.871 & 0.875 \\
\hline Title of the lesson & 0.857 & 0.742 \\
\hline Instructional objective & 0.969 & 0.968 \\
\hline Special Education Needs & 1 & 1 \\
\hline Lesson description (DTLA) & 0.897 & 0.758 \\
\hline Lesson stages & 0.412 & 0.324 \\
\hline Lesson approaches & 0.980 & 0.869 \\
\hline $\begin{array}{l}\text { Generic competences and } \\
\text { issues }\end{array}$ & 0.369 & 0.214 \\
\hline Lesson evaluation & & 1 \\
\hline
\end{tabular}

The inter-rater reliability for LPEF was similarly based on the same LPAP raters scoring a sample of the same $32 \mathrm{LPs}$. The Spearman's rho among the raters was computed and found to be .93, while the weighted Kappa was found to be .79 across all selected LPEF items.

Alongside rate agreement among raters, Cohen's Kappa is used to remove agreement by chance (Cohen, 1988). Its interpretation is moderate when $\mathrm{K}$ is $>.5$, reasonable when $\mathrm{K}$ is $>.7$, and excellent when $\mathrm{K}$ is $>.8$. For ordinal data, the Spearman-Brown coefficient is considered, and a weighted Kappa is computed to provide an ordinal outcome. 
To supplement our study results, we have crafted and validated a model lesson plan that any physics teacher can refer to (see Appendix C).

\section{Data Analysis and Results}

Each rater has rated all 32 LPs into four LPAP scales according to each of the 27 LPAP items. We have averaged the results from both raters and computed means for each item. All teachers did not use the REB LP format. This is the reason why tracking the steps of inquiry techniques was difficult. The new REB LP format appears in the textbooks printed in 2019 (REB, 2019). However, teachers did not yet adapt themselves to it. This may be the lack of emphasis from REB. Teachers should be well informed of their roles. This format has segments in the development and conclusion sections of the LP, where the development section of the LP comprises discovery activities, presentation learners' findings production, and exploitation of findings/production, and the conclusion section comprises conclusion/summary and assessment/homework.

It can be found that there is a variety rate across all 27 items on a 4-point scale. Thus, some items were rated one (on scale 1) while others were rated four (on scale 4). This is to clarify that, for instance, most of the teachers did not write SEN or wrote "none" or "-" or a number only and scored below an average score of 2.0. However, none of this written SEN was addressed in the body of the lesson. Thus, both raters rated this item on scale-1. However, they connect the lesson title to the syllabus - as both raters rated this item into the scale- 4 . In other words, teachers consult the syllabus in formulating the lesson topic. All teachers write the IO in all the LPs, although they miss some components, mostly condition and standard (see Table 3).

Table 3: LPAP mean scores from two raters

\begin{tabular}{|c|c|c|c|c|c|}
\hline & & $\begin{array}{l}\text { Mean } \\
\text { Rater1 }\end{array}$ & $\begin{array}{l}\text { Mean } \\
\text { Rater2 }\end{array}$ & $\begin{array}{l}\text { Mean } \\
\text { Rater1 } \\
\& 2\end{array}$ & $\begin{array}{l}\text { SD } \\
\text { Rater1 } \\
\& 2\end{array}$ \\
\hline Item1 & Written KUC and how it is written & 3.6 & 3.7 & 3.6 & 0.95 \\
\hline Item2 & Format of the lesson title & 3.8 & 3.8 & 3.8 & 0.46 \\
\hline Item3 & Lesson title time-bound & 3.2 & 3.8 & 3.5 & 1.11 \\
\hline Item 4 & Syllabus connected to the lesson title & 4 & 4 & 4 & 0 \\
\hline Item5 & Written IO and how it is written & 4 & 4 & 4 & 0 \\
\hline Item6 & Number of IO components & 3.5 & 3.4 & 3.5 & 0.5 \\
\hline Item7 & Written SEN and description & 1.8 & 1.8 & 1.8 & 0.84 \\
\hline Item8 & $\begin{array}{l}\text { Addressed SEN and the place where } \\
\text { it is addressed }\end{array}$ & 1 & 1 & 1 & 0 \\
\hline Item9 & Written DTLA and how it is written & 3.1 & 3.1 & 3.1 & 1.31 \\
\hline Item10 & Lesson introduction & 3.2 & 3.2 & 3.2 & 0.42 \\
\hline Item11 & Lesson development & 3.5 & 3.5 & 3.5 & 0.5 \\
\hline Item12 & Lesson conclusion & 3.2 & 3.2 & 3.2 & 0.42 \\
\hline Item13 & $\begin{array}{l}\begin{array}{l}\text { Components of the lesson } \\
\text { development }\end{array} \\
\end{array}$ & 1.8 & 1.1 & 1.4 & 0.53 \\
\hline Item14 & Components of the lesson conclusion & 2.1 & 1.3 & 1.7 & 0.91 \\
\hline Item15 & TR in Introduction to the lesson & 1.3 & 1.3 & 1.3 & 0.67 \\
\hline
\end{tabular}




\begin{tabular}{llllll}
\hline Item16 & TR in Development of the lesson & 2.4 & 2.4 & 2.4 & 1.14 \\
\hline Item17 & TR in Conclusion of the lesson & 1.6 & 1.6 & 1.6 & 0.92 \\
\hline Item18 & FA in Introduction to the lesson & 2.6 & 2.7 & 2.6 & 0.76 \\
\hline Item19 & FA in Development of the lesson & 3.1 & 3.1 & 3.1 & 0.64 \\
\hline Item20 & FA in Conclusion of the lesson & 2.9 & 3 & 3 & 0.28 \\
\hline Item21 & ALT in Introduction to the lesson & 2.9 & 2.9 & 2.9 & 0.44 \\
\hline Item22 & ALT in Development of the lesson & 3.1 & 3.2 & 3.2 & 1.01 \\
\hline Item23 & ALT in Conclusion of the lesson & 3.2 & 3.2 & 3.2 & 0.68 \\
\hline Item24 & If visualized, was the ALT used with & 4 & 2.3 & 3.1 & 1.17 \\
& purpose? & 4 & 3.7 & 3.8 & 0.37 \\
\hline Item25 & GCs & 3.9 & 3.6 & 3.8 & 0.62 \\
\hline Item26 & CCIs & 2.6 & 2.6 & 2.6 & 0.83 \\
\hline Item27 & TSE & & & & \\
\hline
\end{tabular}

Active learning techniques (ALT) were mostly provided than formative assessment (FA) and teaching resources (TR) (refer to Appendix B for more detail). They were observed mostly in the Development and Conclusion of the lesson than in the Introduction. This was reflected by the high percentage of LPs in the Development of the lesson (47\%) and the Conclusion of the lesson (28\%). The TRs were not visualized compared to FA and ALT in both parts of the lesson-Introduction, Development, and Conclusion. This was reflected by the highest percentages of LPs rated into scale 1 "not visualized" - Introduction $(87.5 \%)$, Development (37.5\%), and Conclusion (68.8\%) (see Figure 1).

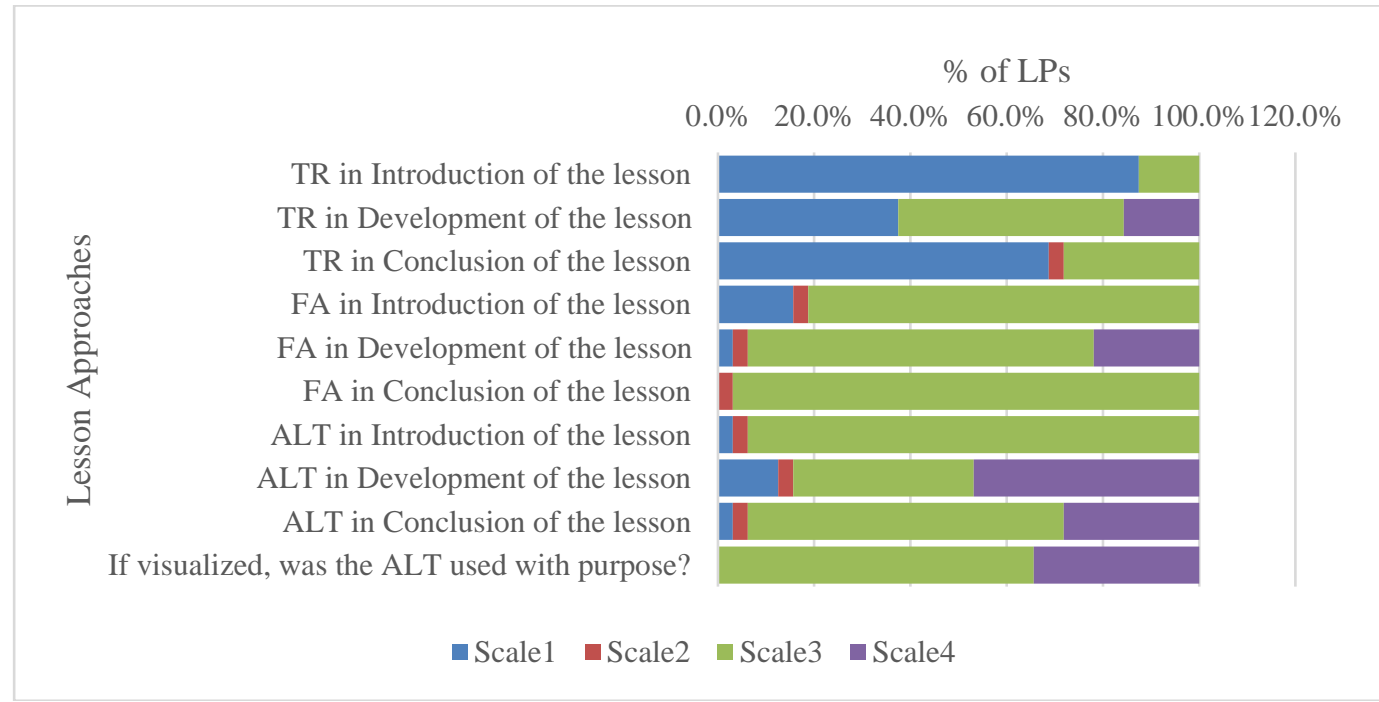

Figure 1: Distribution of LPs into the Lesson Approaches group. Scale-1 "Not visualized" scale-2 "Visualized but not clear" scale-3 "At least one is visualized and clear" scale-4 "More than one is visualized and clear." On the "If visualized, was the ALT used with purpose?" the scale-1 is "Definitely not," scale-2 is "Probably not" scale-3 is "Probably yes," and scale-4 is "Definitely yes."

The descriptive statistics associated with LPAP scales across five physics teachers are reported in Table 4 . We evaluated the assumption of normality to satisfy 
distribution in these five teachers; the Skewness and Kurtosis were found negative. Skew is about distributional symmetry, while Kurtosis is the thickness of the tails and the center of the distribution (Blanca, Arnau, López-Montiel, Bono \& Bendayan, 2013). Thus, the data are not normally distributed; instead, they are negatively skewed. Teachers are mostly ranked towards the scale- 4 of LPAP. Similarly, the data are negative Kurtosis distribution as the data in distribution is short and wide.

Table 4: Descriptive statistics

\begin{tabular}{lllllll}
\hline & Mean & & $\begin{array}{l}\text { Std. } \\
\text { Deviation }\end{array}$ & Variance & Skewness & Kurtosis \\
\hline & Statistic & $\begin{array}{l}\text { Std. } \\
\text { Error }\end{array}$ & Statistic & Statistic & Statistic & Statistic \\
\hline MeanTeacher1 & 2.778 & .1945 & 1.0105 & 1.021 & -.496 & -.858 \\
\hline MeanTeacher2 & 2.926 & .1910 & .9924 & .985 & -.691 & -.716 \\
\hline MeanTeacher3 & 2.919 & .1803 & .9368 & .878 & -.664 & -.370 \\
\hline MeanTeacher4 & 2.892 & .2035 & 1.0576 & 1.118 & -.655 & -.843 \\
\hline MeanTeacher5 & 2.639 & .2182 & 1.1337 & 1.285 & -.416 & -1.253 \\
\hline
\end{tabular}

In order to test the hypothesis that teachers plan their lesson similarly, we performed the correlation analysis and analysis of variances (ANOVA). A .929 Cronbach alpha coefficient was found. Thus, the correlation is highly positive among five teachers. The independent between-groups ANOVA did not yield a statistically significant difference, $F(26,4)=1.386, p=.244$. Thus, we retain a null hypothesis of no difference between teachers in terms of LP preparation. The teachers' means are crossly related, ranging from Teacher $5(M=2.639)$ to Teacher $2(M=2.926)$.

Among 32 LPs, only four LPs open the Introduction of the lesson by revising the last lesson. This is important from the constructivist point of view in a way that students should build on existing knowledge. Analyzing deep the formative assessment and active learning techniques, we employed the LPEF tool to compute scores on cognitive and affective levels of Bloom taxonomy to respond to the FA and the inquiry techniques as an ALT for most experiment-based LPs. The digits under table 4 are average scores from two raters at a 1-to 4-point Likert type scale from 1 "the item was definitely not appeared" to 4 "the item has definitely appeared."

From the Bloom taxonomy perspectives' cognitive level, teachers plan for only delivering knowledge and assure that understanding is set in. This is shown by the mean score (4.0) across all 32 LPs. Even the application of what was learned was found below the average of 2.0. Similarly, at the adequate level of Bloom taxonomy perspectives, teachers care for making their students receive information $(M=4.0)$ and attend $(M=4.0)$ to and respond $(M=3.1)$ asked questions (see Table 5). 
Table 5: Results from the Lesson Plan Evaluation Form 1: Definitely not, 2: Probably not, 3: Probably yes, and 4: Definitely yes

\begin{tabular}{|c|c|c|c|c|c|c|c|c|c|c|c|c|c|c|c|c|}
\hline \multirow[b]{2}{*}{ LP code } & \multicolumn{6}{|c|}{ Cognitive Level of Bloom Taxonomy } & \multicolumn{5}{|c|}{ Affective Level of Bloom Taxonomy } & \multicolumn{5}{|c|}{ Inquiry techniques } \\
\hline & $\begin{array}{l}0 \\
00 \\
0 \\
\frac{8}{3} \\
0 \\
\Xi \\
E\end{array}$ & 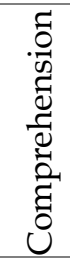 & 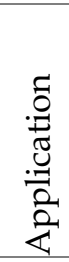 & $\frac{\frac{n}{n}}{\frac{\pi}{\mathbb{J}}}$ & 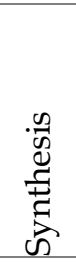 & 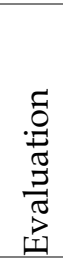 & 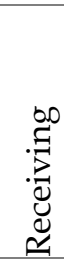 & 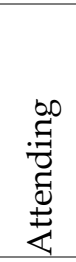 & 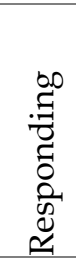 & 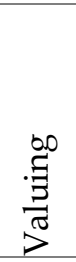 & 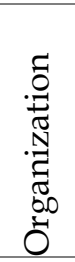 & 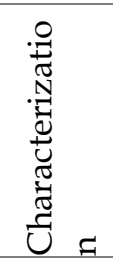 & 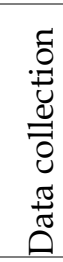 & 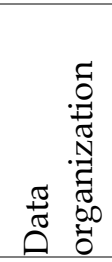 & 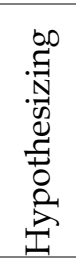 & 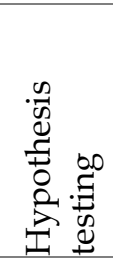 \\
\hline PT1A & 4 & 4 & 1 & 2 & 1 & 1 & 4 & 4 & 4 & 1 & 1 & 1 & 1 & 1 & 1 & 1 \\
\hline PT1B & 4 & 4 & 1 & 2 & 1 & 2 & 4 & 4 & 3 & 1 & 1 & 1 & 1 & 1 & 1 & 1 \\
\hline PT1C & 4 & 4 & 1 & 2 & 1 & 2 & 4 & 4 & 3 & 1 & 1 & 1 & 1 & 1 & 1 & 1 \\
\hline PT1D & 4 & 4 & 1 & 1 & 1 & 1 & 4 & 4 & 4 & 1 & 1 & 1 & 1 & 1 & 1 & 1 \\
\hline PT1E & 4 & 4 & 4 & 2 & 2 & 2 & 4 & 4 & 4 & 1 & 3 & 2 & & & & \\
\hline PT2A & 4 & 4 & 3 & 2 & 1 & 1 & 4 & 4 & 3 & 1 & 3 & 1 & 3 & 3 & 1 & 1 \\
\hline PT2B & 4 & 4 & 3 & 2 & 1 & 1 & 4 & 4 & 3 & 1 & 3 & 1 & 3 & 3 & 1 & 1 \\
\hline PT2C & 4 & 4 & 1 & 1 & 1 & 2 & 4 & 4 & 4 & 1 & 1 & 1 & & & & \\
\hline PT2D & 4 & 4 & 1 & 1 & 1 & 2 & 4 & 4 & 4 & 1 & 1 & 1 & & & & \\
\hline PT2E & 4 & 4 & 1 & 1 & 1 & 3 & 4 & 4 & 4 & 1 & 1 & 1 & & & & \\
\hline PT2F & 4 & 4 & 1 & 1 & 1 & 1 & 4 & 4 & 2 & 1 & 1 & 1 & 1 & 1 & 1 & 1 \\
\hline PT2G & 4 & 4 & 1 & 1 & 1 & 1 & 4 & 4 & 3 & 1 & 1 & 1 & & & & \\
\hline PT2H & 4 & 4 & 1 & 1 & 1 & 1 & 4 & 4 & 3 & 1 & 1 & 1 & & & & \\
\hline PT2J & 4 & 4 & 1 & 1 & 1 & 1 & 4 & 4 & 3 & 1 & 1 & 1 & & & & \\
\hline PT3A & 4 & 4 & 2 & 1 & 1 & 2 & 4 & 4 & 3 & 1 & 1 & 1 & & & & \\
\hline PT3B & 4 & 4 & 2 & 2 & 1 & 2 & 4 & 4 & 2 & 1 & 2 & 1 & 2 & 3 & 1 & 1 \\
\hline PT3C & 4 & 4 & 1 & 1 & 1 & 1 & 4 & 4 & 3 & 1 & 1 & 1 & & & & \\
\hline PT3D & 4 & 4 & 2 & 1 & 1 & 2 & 4 & 4 & 4 & 1 & 1 & 1 & 1 & 1 & 1 & 1 \\
\hline
\end{tabular}




\begin{tabular}{|c|c|c|c|c|c|c|c|c|c|c|c|c|c|c|c|c|}
\hline PT3E & 4 & 4 & 2 & 1 & 1 & 2 & 4 & 4 & 4 & 1 & 1 & 1 & 1 & 1 & 1 & 1 \\
\hline PT3G & 4 & 4 & 2 & 1 & 1 & 2 & 4 & 4 & 4 & 1 & 1 & 1 & 4 & 3 & 1 & 1 \\
\hline PT3I & 4 & 4 & 3 & 2 & 1 & 2 & 4 & 4 & 4 & 1 & 1 & 1 & & & & \\
\hline PT3K & 4 & 4 & 3 & 2 & 1 & 2 & 4 & 4 & 4 & 1 & 1 & 1 & & & & \\
\hline PT3M & 4 & 4 & 2 & 1 & 1 & 1 & 4 & 4 & 2 & 1 & 2 & 1 & 1 & 1 & 1 & 1 \\
\hline PT3N & 4 & 4 & 1 & 1 & 1 & 1 & 4 & 4 & 4 & 1 & 1 & 1 & & & & \\
\hline PT4A & 4 & 4 & 2 & 2 & 2 & 3 & 4 & 4 & 3 & 3 & 3 & 2 & & & 4 & 2 \\
\hline PT4B & 4 & 4 & 1 & 1 & 1 & 1 & 4 & 4 & 2 & 1 & 2 & 1 & & & & \\
\hline PT4C & 4 & 4 & 3 & 2 & 3 & 3 & 4 & 4 & 2 & 4 & 2 & 2 & & & 3 & \\
\hline PT4D & 4 & 4 & 3 & 2 & 3 & 3 & 4 & 4 & 2 & 4 & 2 & 2 & & & 3 & \\
\hline PT4E & 4 & 4 & 3 & 2 & 3 & 3 & 4 & 4 & 2 & 4 & 2 & 2 & & & 3 & \\
\hline PT4F & 4 & 4 & 3 & 2 & 3 & 3 & 4 & 4 & 2 & 4 & 2 & 2 & & & 3 & \\
\hline PT5A & 4 & 4 & 1 & 1 & 1 & 1 & 4 & 4 & 2 & 1 & 1 & 1 & & & & \\
\hline PT5B & 4 & 4 & 2 & 1 & 1 & 3 & 4 & 4 & 2 & 1 & 1 & 1 & & & & \\
\hline Mean & 4.0 & 4.0 & 1.8 & 1.4 & 1.3 & 1.8 & 4.0 & 4.0 & 3.1 & 1.4 & 1.5 & 1.2 & 1.7 & 1.7 & 1.6 & 1.1 \\
\hline St. Dev & 0.0 & 0.0 & 0.9 & 0.5 & 0.7 & 0.8 & 0.0 & 0.0 & 0.8 & 1.0 & 0.7 & 0.4 & 1.1 & 1.0 & 1.1 & 0.3 \\
\hline
\end{tabular}


The space with no number refers to LPs that were not related to experimentation. We then noted that other LPs would implement inquiry techniques. However, such practice was not visualized. It seems that teachers are not aware of inquirybased learning techniques and those who are aware of them think that it can only be implemented in experiment related lessons. Our results show that the use of inquiry techniques was below the average of 2.0. Contrary wise, in the Ferrell (1992) study, the LPEF analysis findings indicate that teachers follow an excellent teaching practice during their lesson planning. Only in four LPs, the teacher planned to ask students to hypothesize or predict the outcome of observation (see Table 5). This is in line with a study by Ndihokubwayo, Uwamahoro \& Ndayambaje (2020), who, via RTOP results, found that teachers do not promote prediction among students. The inquiry is associated with science, a complex activity involving observation, questioning, examining various sources of information to reveal what is already known in the light of experimental evidence, investigating inferences by gathering/analyze/and interpret data, proposing answers and explanations, and communicating the outcome (Mugabo, 2012).

\section{Discussion of Practical Implication}

Teacher 1 planned the lessons from the KUC "by the end of this unit; the learner should be able to explain the properties of lenses and image formation by lenses" from S4.

Teacher 1 fully used group formulation in all LPs, where he emphasized on mixing girls and boys as a criterion of the group formulation. This may be caused by the gender inclusion expected in the 8 CCIs (REB, 2015b). This inclusion is subtle. However, teachers should go beyond this and ensure that boys and girls have the same learning rights. Contrary wise, Teacher 4 mentioned it. He wrote: "gender balance: boys and girls are given equal responsibilities." Teachers should also emphasize the inclusion of able students and struggling students to employ a specific ALT purposively (refer to Appendix B for more detail). In presenting the results, the teacher only uses the group leader. This act may discourage other students and pressure the group leader. It is better to randomly select the presenter so that everyone is ready to work as none knows who will present the group findings. In describing the competences to be accommodated, the teacher usually mentions: "skills in organizing scattered data to develop systematic, observation, and detailed presentation"; however, in the teacher or students' activity, there was not appearance of any doing an experiment, observing nature or inquiry. He also wrote that "skills in report presentation, for example, in Microsoft PowerPoint" while in the teacher or student activities, it appears presenting on the blackboard. An LP serves as a map guiding the teacher during the teaching process (Ndihokubwayo et al. 2020). However, it seems it is a formality. For instance, in the "learning materials" place, the teacher mentions some materials such as a calculator, internet connection. However, he does not describe how they will be used in the main lesson (teacher and learner activities). Straessle (2014) found that many teachers use written lesson plans but they do not often refer to them during class delivery. Therefore, teachers need to take LPs as their road map toward effective lesson delivery. Teachers should write their lesson plan with full consideration. They should revise it to check everything is in place. Refer to a model lesson plan in Appendix C3 as a standardized and full lesson plan. 
Teacher 2 planned the lessons from the KUC "by the end of this unit, the learner should be able to explain the properties of lenses and image formation by lenses" from S4, and "the learner should be able to analyze the nature of light" from S5.

Teacher 2 outlined the activities to be done by students and teachers. She took the students into experiments and discussion of results through group work. She said the teacher should do the first activity of the experiment while students do the next step. However, this is good; however, this is good; she may be sure that students cannot do even the first step if the teacher guides them skillfully. She outlined the GCs and CCIs without explaining how they will be catered and achieved. Thus, their role according to each and specific activity is lost. Teacher 2 differs from Teacher 1 in the way that she planned for the experiment, although she did not provide the name of an experiment to be done or specifies its steps. The teacher considered writing a lab report as an assessment during the Conclusion of the lesson. The study of Amanda G. Sawyer showed that teachers vary in the choices of resources for lesson planning due to their different experiences.

Teacher 3 planned the lessons from the KUC "by the end of this unit; the learner should be able to explain the properties of lenses and image formation by lenses" and "by the end of this unit, the learner should be able to analyze the function of the simple and compound microscope" from S4.

In the lesson on Measuring the focal length of the convex lens, the teacher set the IO well (refer to Appendix B for more detail). For instance, he wrote, "given lenses and other necessary apparatus, learners should be able to determine the focal length of a convex lens effectively." This is in line with the Straessle (2014) study, where teachers did not differentiate among the components of lesson planning, although they care about clear learning objectives than other components.

Most of the time, the teacher introduces before learners are assigned to the group works. He then emphasizes that students should follow his explanation actively. In some of the LPs, the teacher described the SEN though he did not address them in the lesson development. For instance, he wrote, "some students are quick while others are slow in learning." Somewhere he even specifies the number "five students have difficulties in understanding English" or "five students have disruptive behavior." Always the teacher summarizes or concludes the lesson, and students take notes.

Teacher 4 planned the lessons from the KUC "by the end of this unit; the learner should be able to analyze the nature of light" from S5.

Most of all the teachers used a particular ALT without purpose. For instance, Teacher 4 started by assigning students into groups. The use of such group work should take a source, for example, after assigning students with individual work, and the teacher notices difficulties among students to perform the given activity or exercise. Most of the teachers ask questions in the Conclusion and expect students to respond to those questions. However, these questions are not mentioned. These questions or exercises should be different from what was discussed in the lesson to avoid memorization and promote thinking. Thus, 
students should use what was learned to answer questions or perform exercises and not copy what they learned. This will increase their critical thinking as they achieved competence, and the lesson will be viewed at a wide-angle (to be used in various contexts). Our results show that teachers do not plan for a significant assignment that reflects students' context and the use of what was learned clearly. The Straessle (2014) study revealed that when creating assignments, teachers use real-world connections significantly more frequently than any other facet. This real-world context should be reflected when teachers emphasize allowing students to connect themselves and what they learn to their real-life situations. Moreover, this is well outlined and recommended in the syllabus (REB, 2015a) daily use.

Teacher 4 planned to request students to interpret their results. This is very important in promoting critical thinking. It alerts students that observation or experimentation is not a standalone lesson objective; instead, a further inference of the results is necessary to get the meaning of what they learn. Most of the teachers care about critical thinking as a GC. Only teacher 4 emphasizes long-life learning. For instance, "students will develop long-life learning by taking the initiative to update knowledge and skills with minimum external support." This is very crucial to motivate such senior five students to look further in their future. It may help them to plan for their future studies and career.

Teacher 4 describes the "DTLA" well. For instance, in the lesson of "measuring the Plank's constant," he wrote the DTLA: "using an electronic circuit containing a LED power supply, digital millimeter, and a digital voltmeter, learners with the help of the teacher describe how to measure Plank's constant." This may guide anyone who reads the LP (for instance, before observing class) on what will be done during the teaching and learning process. Teacher 4 encourages the students to make a prediction. This helps students to observe and think by relating their prerequisite knowledge to a new observation. Teachers outline what will be done in the lesson but do not describe what and how they will be done. In the case of teaching activity, if, for example, the teacher is not available to teach the lesson, Deputy Of Studies will not have an opportunity to assign another teacher to teach such lessons as it is not well and fully elaborated.

Teacher 5 planned the lessons from the KUC "by the end of this unit; the learner should be able to explain the properties of lenses and image formation by lenses" from S4 and "by the end of this unit, the learner should be able to analyze the nature of light" from S5.

Teacher 5 planed to provide short notes to students and give time to copy notes. He is brief in planning all the LP steps, even in writing the KUC in full. Thus, he shortened the KUC. He wrote, "explain the properties of lenses."

Most of the teachers start the introduction section by asking students questions about the previous lesson. None of the teachers uses the LP format segmenting the development section into discovery activities, presentation learners' findings production, exploitation findings production, and the conclusion section into conclusion/summary and assessment/homework. This shows why all LPs show a poor description of activities to be done during the teaching and learning process. Thus, if the teacher fills the LP format by planning for these components 
of development and conclusion sections, the LP would be clearer and directive to any other teacher or any classroom observer.

\section{Conclusion and limitations}

In this study, LPAP findings showed that physics teachers' lesson plans do not reflect well on the competence-based curriculum. Teachers do not follow the REB LP format, do not cater to slow learners, and are reluctant to use effective active learning techniques. There is no need to limit teachers on which lesson plan format to use; however, REB needs to guide them effectively during in-service teacher training. Probably, what is essential is not the format, rather what to consider while planning a lesson. Our findings show that the LPEF analysis indicates that teachers do not use higher levels of the cognitive and affective domains. Teachers do not consider following inquiry techniques too. Data from the lesson plan analysis should be supplemented by classroom observation. Although reviewing lesson plans added little to the accuracy of rating a teacher's performance, however, this is a reasonable prediction that if a good preparation were considered, the reformed teaching would also increase. The limitations of our study lie on small sample disabling us to generalize our results. Therefore, further studies should focus on the scheme of work as an important pedagogical document and check its alignment to the lesson plan with a sounding teachers' sample as well as lesson delivery.

\section{Acknowledgment}

This research was financially supported by the African Center of Excellence for Innovative Teaching and Learning of Mathematics and Science (ACEITLMS) of the University of Rwanda (UR). We would like to extend our gratitude to the individuals who evaluated the lesson plan presented in this research. Without their comments, critics, and views, the lesson presented would not have rich information and fruitful to our dedicated teachers. This is why Ms. Pascasie Nyirahabimana, Mr. Hashituky Telesphore Habiyaremye, Mr. Jean Nepomscène Twahirwa, Mr. Jean de Dieu Nkurikiyimana, and Ms. Jeannette Nyirahagenimana, all their inputs are acknowledged. We highly appreciate the editor and reviewers from IJLTER; their comments and suggestions were valuable and helped us improve this study. We also thank Mr. Fidèle Ukobizaba and Miss Juliette Itangishatse, who commented on the manuscript before sending it to the IJLTER for review and publication. This work was also inspired by JICA experts that worked for the SIIQS project; therefore, they are acknowledged.

\section{References}

Abbott, P., Sapsford, R., \& Rwirahira, J. (2015). Rwanda's potential to achieve the millennium development goals for education. International Journal of Educational Development, 40, 117-125. doi:10.1016/j.ijedudev.2014.12.007

Birindwa, C., \& Atwebembeire, A. (2016a). Physics for Rwanda Secondary Schools: Teacher's Guide Book 4. Kigali: Fountain Publishers Rwanda Ltd.

Birindwa, C., \& Atwebembeire, A. (2016b). Physics for Rwanda Secondary Schools Learner's Book 4. Kigali: Fountain Publishers Rwanda Ltd.

Blanca, M. J., Arnau, J., López-Montiel, D., Bono, R., \& Bendayan, R. (2013). Skewness and 
kurtosis in real data samples. Methodology, 9, 78-84. doi:10.1027/16142241/a000057

Boikhutso, K. (2010). The theory into practice dilemma: Lesson planning challenges facing botswana student-teachers. Improving Schools, 13(3), 205-220. doi:10.1177/1365480210385668

Byusa, E., Kampire, E., \& Mwesigye, A. R. (2020). Analysis of Teaching Techniques and Scheme of Work in Teaching Chemistry in Rwandan Secondary Schools. EURASIA Journal of Mathematics, Science and Technology Education, 16(6), 1-9. doi:10.29333/ejmste/7833

Causton-Theoharis, J. N., Theoharis, G. T., \& Trezek, B. J. (2008). Teaching pre-service teachers to design inclusive instruction: A lesson planning template. International Journal of Inclusive Education, 12(4), 381-399. doi:10.1080/13603110601156509

Cohen, J. (1988). Statistical power analysis for the behavioral sciences (2nd ed.). Hillsdale, NJ: Lawrence Earlbaum Associates.

Diem, H. T. T., \& Thathong, K. (2019). Enhancing the pre-service biology teachers to construct better lesson plans: A lesson study. International Journal of Learning, Teaching and Educational Research, 18(11), 218-231. doi:10.26803/ijlter.18.11.13

Ferrell, B. G. (1992). Gifted Child Quarterly. Gifted Child Quarterly, 36(1), 23-26. doi:10.1177/001698629203600106

Jacobs, C. L., Martin, S. N., \& Otieno, T. C. (2008). Instrument for Formative and Summative Program Evaluation of a Teacher Education Program. Science Teacher Education, 92, 1097-1126. doi:10.1002/sce.20277

JICA. (2020). The Project for Supporting Institutionalizing and Improving Quality of SBI Activity ( SIIQS ) Project Completion Report The Project for Supporting Institutionalizing and Improving Quality of SBI Activity (SIIQS) Project Completion Report. Kigali. Retrieved from https://openjicareport.jica.go.jp/pdf/12327383.pdf

Mugabo, R. L. (2012). Introduction of Inquiry-based Science Teaching in Rwandan Lower Secondary Schools: Teachers' attitudes and perceptions. University of KwaZulu-Natal.

Ndihokubwayo, K., Byukusenge, C., Byusa, E., Habiyaremye, H. T., Mbonyiryivuze, A., \& Mukagihana, J. (2020). Lesson Plan Analysis Protocol (LPAP): Training Manual. Retrieved from https://www.researchgate.net/publication/347388283_LPAP_Training_Manual _Final_version_Suplementary_materials?channel=doi\&linkId=5fda6b89299bf140 8816e04d\&showFulltext=true

Ndihokubwayo, K., Uwamahoro, J., \& Ndayambaje, I. (2020a). Effectiveness of PhET Simulations and YouTube Videos to Improve the Learning of Optics in Rwandan Secondary Schools. African Journal of Research in Mathematics, Science and Technology Education, 24(2), 253-265. doi:10.1080/18117295.2020.1818042

Ndihokubwayo, K., Uwamahoro, J., \& Ndayambaje, I. (2020b). Implementation of the Competence-Based Learning in Rwandan Physics Classrooms: First Assessment Based on the Reformed Teaching Observation Protocol. EURASIA Journal of Mathematics, Science and Technology Education, 16(9), 1-8. doi:10.29333/ejmste/8395

Ndihokubwayo, K., Uwamahoro, J., Ndayambaje, I., \& Ralph, M. (2020). Light phenomena conceptual assessment: an inventory tool for teachers. Physics Education, 55(3), 035009. doi:10.1088/1361-6552/ab6f20

Nsengimana, T., Rugema Mugabo, L., Hiroaki, O., \& Nkundabakura, P. (2020). Reflection on science competence-based curriculum implementation in Sub-Saharan African countries. International Journal of Science Education, Part B, O(0), 1-14. doi:10.1080/21548455.2020.1778210

Orodho, A., Nzabarirwa, W., Odundo, P., Waweru, P. N., \& Ndayambaje, I. (2016). 
Quantitative and Qualitative Research Methods. A Step by Step Guide to Scholarly Excellence. Nairobi: Kanezja Publishers \& Entreprises.

Pramoolsook, I., \& Magday, W. D. (2019). Move confirmation and teaching strategy identification of english student-teachers' lesson plans in the Philippines: A rhetorical framework for novice teachers. International Journal of Learning, Teaching and Educational Research, 18(12), 150-173. doi:10.26803/ijlter.18.12.10

Ruys, I., van Keer, H., \& Aelterman, A. (2012). Examining pre-service teacher competence in lesson planning pertaining to collaborative learning. Journal of Curriculum Studies, 44(3), 349-379. doi:10.1080/00220272.2012.675355

REB. (2015a). Advanced level Physics syllabus. Kigali, Rwanda: Rwanda Education Board, Ministry of Education.

REB. (2015b). Comptence-Based Curriculum. Curriculum Framework Pre-Primary to Upper Secondary. Kigali, Rwanda: Rwanda Education Board, Ministry of Education.

REB. (2015c). Roll out of the Competence-Based Curriculum: Teacher Training Manual (1st phase). Kigali. Rwanda: Rwanda Education Board, Ministry of Education.

REB. (2017). Teacher Training Manual - Reflections on Teaching Practice and Focus on Assessement (3rd Phase). Kigali, Rwanda: Rwanda Education Board, Ministry of Education.

REB. (2019). Subsidiary Mathematics Senior 6 Teacher' s Guide. Kigali, Rwanda: Rwanda Education Board, Ministry of Education.

Sawyer, A. G., \& Myers, J. (2018). Seeking comfort: How and why preservice teachers use internet resources for lesson planning. Journal of Early Childhood Teacher Education, 39(1), 16-31. doi:10.1080/10901027.2017.1387625

Straessle, M. W. J. (2014). Teachers' perspectives of effective lesson planning: A comparative analysis (College of William and Mary in Virginia). College of William and Mary in Virginia. doi:10.25774/w4-8swa-7371

Theoharis, G., \& Causton-Theoharis, J. (2011). Preparing pre-service teachers for inclusive classrooms: Revising lesson-planning expectations. International Journal of Inclusive Education, 15(7), 743-761. doi:10.1080/13603110903350321

\section{Appendices}

\section{Appendix A: Pedagogical document reviewed}

We have requested LPs from 11 teachers. We analyzed 32 lesson plans from five teachers, where 24 were from S4 while eight were from S5. Fourteen LPs were single lessons of 40 minutes period, 10 were double periods of 80 minutes each, while 8 had triple periods of 120 minutes each.

Table A1: Lesson Plans collected alongside the optics content

\begin{tabular}{|c|c|c|c|}
\hline no & Topic & Date & Min \\
\hline \multicolumn{4}{|c|}{ S4 lesson plans } \\
\hline 1 & $\begin{array}{l}\text { Magnification of the lens, Power of the lens, and } \\
\text { exercises on formula of the lens }\end{array}$ & $6 / 2 / 2019$ & 40 \\
\hline 2 & Determination of the focal length of the lens & $8 / 2 / 2019$ & 40 \\
\hline 3 & $\begin{array}{l}\text { Refraction through a prism (deviation of light by a } \\
\text { prism) }\end{array}$ & $15 / 2 / 2019$ & 40 \\
\hline 4 & $\begin{array}{l}\text { The angle of minimum deviation and } \\
\text { determination of the refractive index }\end{array}$ & $16 / 2 / 2019$ & 40 \\
\hline 5 & $\begin{array}{l}\text { Summary (Exercises) of all topics in this unit by } \\
\text { giving exercises }\end{array}$ & $21 / 2 / 2098$ & 40 \\
\hline
\end{tabular}




\begin{tabular}{|c|c|c|c|}
\hline 1 & Minimum deviation angles in prisms & $6 / 1 / 2019$ & 40 \\
\hline 2 & Physical features and types of thin lenses & $21 / 1 / 2019$ & 40 \\
\hline 3 & The image formed by a thin lens & $23 / 1 / 2019$ & 40 \\
\hline 4 & The formula of a thin lens & $28 / 1 / 2019$ & 40 \\
\hline 5 & Refraction of light through a prism & $29 / 1 / 2019$ & 40 \\
\hline 6 & Angles of minimum deviation and refractive index & $30 / 1 / 2019$ & 40 \\
\hline 7 & Deviation of light by a small angle of the prism & $4 / 2 / 2019$ & 40 \\
\hline 8 & Refractive index of the material & $5 / 2 / 2019$ & 40 \\
\hline 1 & Thin lens & 25/1/2019 & 80 \\
\hline 1 & Thin lens equation & $22 / 1 / 2019$ & 120 \\
\hline 2 & Measurement of the focal length of a convex lens & 29/1/2019 & 120 \\
\hline 3 & $\begin{array}{l}\text { Defects of lenses and their correction. } \\
\text { Refraction through prism }\end{array}$ & $5 / 2 / 2019$ & 120 \\
\hline 4 & $\begin{array}{l}\text { Refraction through a prism, a term associated with } \\
\text { refraction through a prism }\end{array}$ & $7 / 2 / 2019$ & 120 \\
\hline 5 & $\begin{array}{l}\text { Deviation of light rays by a glass prism. } \\
\text { The angle of minimum deviation and } \\
\text { determination of the refractive index }\end{array}$ & $12 / 02 / 2019$ & 120 \\
\hline 6 & The angle of minimum deviation of a glass prism & $14 / 2 / 2019$ & 120 \\
\hline 7 & Lens maker's equation (Full lens equation) & $19 / 2 / 2019$ & 120 \\
\hline 8 & $\begin{array}{l}\text { Definition of an optical instrument and angular } \\
\text { magnification, the human eye, and visual angle }\end{array}$ & $25 / 2 / 2019$ & 80 \\
\hline 9 & $\begin{array}{l}\text { Formation of the image by a lens camera } \\
\text { Slide projector }\end{array}$ & $28 / 2 / 2019$ & 120 \\
\hline 10 & $\begin{array}{l}\text { The terrestrial telescope, Galilean and reflecting } \\
\text { telescope }\end{array}$ & $11 / 3 / 2019$ & 80 \\
\hline \multicolumn{4}{|c|}{ S5 lesson plans } \\
\hline 1 & Compton effect and photon interaction & $25 / 1 / 2019$ & 40 \\
\hline 1 & Wave and particle nature of light & $18 / 1 / 2019$ & 80 \\
\hline 1 & The measure of Planck's constant & $22 / 1 / 2019$ & 80 \\
\hline 2 & $\begin{array}{l}\text { Representation, characteristics, and properties of } \\
\text { sounds waves }\end{array}$ & 28/1/2019 & 80 \\
\hline 3 & Blackbody radiation & $31 / 1 / 2019$ & 80 \\
\hline 4 & Guidelines for doing physics practical & $31 / 1 / 2019$ & 80 \\
\hline 5 & Compton effect and photon interaction & $7 / 2 / 2019$ & 80 \\
\hline 6 & Electron microscope & $12 / 2 / 2019$ & 80 \\
\hline
\end{tabular}

\section{Appendix B: Lack of IO and Presence of TR, FA, and ALT among reviewed LPs}

In this appendix, we presented what IO components lacked in LPs written by five teachers (Table B1) and the presence of TR, FA, and ALT among five teachers' LPs (Table B2).

Table B1 Lack of IO 


\begin{tabular}{|l|l|l|l|l|l|}
\hline & Condition & Who & Action & Content & Standard/criterion \\
\hline T1 & 5 & & & & 4 \\
\hline T2 & 5 & & & & 10 \\
\hline T3 & 1 & & & & \\
\hline T4 & 1 & & & & 1 \\
\hline T5 & 2 & & & & 2 \\
\hline
\end{tabular}

Table B2 The presence of TR, FA, and ALT

\begin{tabular}{|c|c|c|c|}
\hline & TR & FA & ALT \\
\hline \multirow[t]{3}{*}{ T1 } & Pen, Pencil (1) & Questioning (5) & Group discussion (4) \\
\hline & Pen, Pencil, Prism (2) & Group activities (2) & Group activities (2) \\
\hline & Pen, Pencil, Prism, Calculator (2) & & \\
\hline \multirow[t]{6}{*}{ T2 } & Prism, pens, paper (3) & Questioning (9) & Lab activities (1) \\
\hline & Ruler, textbooks (1) & Group activities (8) & Discussion (2) \\
\hline & Charts (2) & & Group activities (9) \\
\hline & Blackboard, Chalk Board (1) & & Presentation (2) \\
\hline & & & Demonstration (1) \\
\hline & & & $\begin{array}{l}\text { Providing examples } \\
\text { (1) }\end{array}$ \\
\hline \multirow[t]{8}{*}{ T3 } & Chalks, notebooks, figures & Questioning (5) & Group activities (9) \\
\hline & $\begin{array}{l}\text { Chalks, notebooks, figures, } \\
\text { experiment protocol }\end{array}$ & Group activities (5) & Presentation (3) \\
\hline & Chalks, notebooks, pens. & Exercises, quiz (4) & \\
\hline & Chalks, notebooks, pens, prism & & \\
\hline & $\begin{array}{l}\text { Calculator, notebooks, pens, } \\
\text { Equilateral Glass Prism }\end{array}$ & & \\
\hline & Calculator, notebooks, pens. & & \\
\hline & $\begin{array}{l}\text { Chart, simple microscope, } \\
\text { Calculator, notebooks, pens. }\end{array}$ & & \\
\hline & $\begin{array}{l}\text { Lens Camera, slide projector, pens } \\
\text { (2) }\end{array}$ & & \\
\hline \multirow[t]{6}{*}{ T4 } & String & Questioning (6) & Group discussion (4) \\
\hline & $\begin{array}{l}\text { White and black clothes, sunlight } \\
\text { (2) }\end{array}$ & & Presentation (2) \\
\hline & Marbles & & Group activities (1) \\
\hline & Simple magnifying glasses & & Brainstorming (3) \\
\hline & & & Roleplay (4) \\
\hline & & & Note-taking (6) \\
\hline \multirow[t]{4}{*}{ T5 } & & Questioning (2) & Group discussion (2) \\
\hline & & & Presentation (1) \\
\hline & & & Roleplay (1) \\
\hline & & & Note-taking (2) \\
\hline
\end{tabular}

\section{Appendix C: Model Lesson Plan}

Preparation for class may take many forms. Notably, there are 2 phases before a teacher enters the class and the other two after he/ she enters the class. These are pre-plan, lesson planning, and lesson delivery, and teacher assessment (REB, 2017). The pre-plan is when a teacher thinks about what he/she will do, what is 
needed, which method, materials, or teaching aids he/she will use, how he/she will cater to students, manage class, including varieties among students. After pre-planning mentally, the teacher needs to plan on the paper. This is the lesson planning phase.

To write the model Physics LP, we have chosen to only focus on one topic (Determination of the refractive index of the prism) and planned to be taught in 2 periods (see Table C1). We consulted the syllabus (Rwanda Education Board, 2015a, pp. 23-24), student textbook (Birindwa \& Atwebembeire, 2016b, pp. 49-58), and the teacher's guide (Birindwa \& Atwebembeire, 2016, pp. 1-2 and 18-20).

Table C1 Scheme of work for Unit 1 Thin lenses

\begin{tabular}{|c|c|c|c|}
\hline s/n & Syllabus & Student's book & $\begin{array}{l}\text { Teacher's guide (no of } \\
\text { periods) }\end{array}$ \\
\hline 1 & Characteristics of lenses & \multirow{2}{*}{$\begin{array}{l}\text { Characteristics of lenses } \\
\text { (pp. 4-6) } \\
\text { Terms used in lenses } \\
\text { (pp. 7-11) }\end{array}$} & \multirow{2}{*}{$\begin{array}{l}\text { Types of lenses and } \\
\text { their characteristics (2) }\end{array}$} \\
\hline 2 & $\begin{array}{l}\text { Types of lenses: } \\
\text { converging (double } \\
\text { convex, plan convex, } \\
\text { convex meniscus) and } \\
\text { diverging (double } \\
\text { concave, plano-concave, } \\
\text { concave meniscus) }\end{array}$ & & \\
\hline 3 & $\begin{array}{l}\text { Refraction of light through } \\
\text { lenses. }\end{array}$ & $\begin{array}{l}\text { Refraction of light } \\
\text { through lenses (p. 12) } \\
\text { Properties of images } \\
\text { formed by lenses (pp. } \\
\text { 13-16) }\end{array}$ & $\begin{array}{l}\text { Terms used in lenses, } \\
\text { refraction of light by } \\
\text { lenses, Images formed } \\
\text { by lenses (2) }\end{array}$ \\
\hline 4 & $\begin{array}{l}\text { Ray drawing and } \\
\text { properties of images } \\
\text { formed by lenses for an } \\
\text { object located at different } \\
\text { positions. }\end{array}$ & $\begin{array}{l}\text { Ray diagrams and } \\
\text { properties of images } \\
\text { formed } \\
\text { by lenses (pp. 16-19) } \\
\text { Ray diagrams for a } \\
\text { convex lens (pp. 20-23) }\end{array}$ & $\begin{array}{l}\text { Ray diagrams and } \\
\text { images formed by lenses } \\
\text { (2) }\end{array}$ \\
\hline 5 & $\begin{array}{l}\text { Graphical determination } \\
\text { of the focal length of } \\
\text { lenses }\end{array}$ & $\begin{array}{l}\text { Accurate construction } \\
\text { of ray diagrams (pp. 23- } \\
24 \text { ) }\end{array}$ & $\begin{array}{l}\text { Graphical determination } \\
\text { of the focal length of a } \\
\text { convex } \\
\text { Lens (2) }\end{array}$ \\
\hline 6 & $\begin{array}{l}\text { Thin lens equation, Power } \\
\text { of lens, magnification, and } \\
\text { sign convention. }\end{array}$ & $\begin{array}{l}\text { The thin lens formula } \\
\text { (pp. 24-25) } \\
\text { The sign convention (p. } \\
\text { 25) } \\
\text { Derivation of the lens } \\
\text { formula (pp. 26-29) } \\
\text { Magnification (pp. 29- } \\
\text { 30) } \\
\text { Applications of the lens } \\
\text { formula (pp. 30-33) } \\
\text { Power of the lens (p. 33) } \\
\text { Determination of the } \\
\text { focal length of the lens } \\
\text { (pp. 34-37) }\end{array}$ & $\begin{array}{l}\text { Thin lens formula } \\
\text { (equation), the sign } \\
\text { convention (2) } \\
\text { Magnification, Power of } \\
\text { the lens (2) } \\
\text { Determination of focal } \\
\text { length of a concave lens } \\
\text { (2) }\end{array}$ \\
\hline
\end{tabular}




\begin{tabular}{|c|c|c|c|}
\hline 7 & $\begin{array}{l}\text { Lens combination and } \\
\text { effective focal length }\end{array}$ & \multirow{4}{*}{$\begin{array}{l}\text { Combination of lenses } \\
\text { (pp. 37-40) } \\
\text { Defects of lenses and } \\
\text { their corrections (pp. } \\
40-42 \text { ) }\end{array}$} & \multirow{2}{*}{$\begin{array}{l}\text { Combination of lenses, } \\
\text { and effective focal } \\
\text { length of the lens } \\
\text { combination (2) }\end{array}$} \\
\hline 8 & $\begin{array}{l}\text { Derivation of lenses } \\
\text { formulae }\end{array}$ & & \\
\hline 9 & $\begin{array}{l}\text { Defects and correction of } \\
\text { lenses }\end{array}$ & & \multirow{4}{*}{$\begin{array}{l}\text { Defects of lenses and } \\
\text { their corrections, } \\
\text { refraction } \\
\text { through glass prisms } \\
\text { (Introduction and terms } \\
\text { associated with } \\
\text { refraction through the } \\
\text { prisms) (2) }\end{array}$} \\
\hline 10 & $\begin{array}{l}\text { Applications of combined } \\
\text { lenses }\end{array}$ & & \\
\hline 11 & Refraction through prisms & $\begin{array}{l}\text { Refraction through } \\
\text { prisms (pp. 43-44) }\end{array}$ & \\
\hline 12 & $\begin{array}{l}\text { Terms associated with the } \\
\text { refraction of passing } \\
\text { through a prism }\end{array}$ & $\begin{array}{l}\text { Terms associated with } \\
\text { refraction through a } \\
\text { prism (pp. 44-45) } \\
\text { General formulae for } \\
\text { the prism (pp. } 45-49 \text { ) }\end{array}$ & \\
\hline 13 & $\begin{array}{l}\text { Deviation of light rays by } \\
\text { a glass prism. }\end{array}$ & $\begin{array}{l}\text { Deviation of light by a } \\
\text { prism (pp. 49-51) }\end{array}$ & \multirow[b]{2}{*}{$\begin{array}{l}\text { Determination of } \\
\text { refractive index of the } \\
\text { prism; } \\
\text { Deviation of light by the } \\
\text { prism, Minimum } \\
\text { deviation, } \\
\text { Determination of } \\
\text { refractive index of a } \\
\text { material of a } \\
\text { glass prism using } \\
\text { minimum deviation (2) }\end{array}$} \\
\hline 14 & $\begin{array}{l}\text { The angle of minimum } \\
\text { deviation and the } \\
\text { determination of the } \\
\text { refractive index of a prism }\end{array}$ & $\begin{array}{l}\text { The angle of minimum } \\
\text { deviation and } \\
\text { determination of } \\
\text { refractive index } n \text { of a } \\
\text { material of the prism } \\
\text { (pp. 51-53) } \\
\text { The angle of minimum } \\
\text { deviation and the } \\
\text { refractive index } n \text { of the } \\
\text { material (pp. 53-54) } \\
\text { Deviation of light by a } \\
\text { small angle prism (pp. } \\
54-57 \text { ) } \\
\text { Determination of } \\
\text { refractive index of a } \\
\text { material of a prism (pp. } \\
57-58 \text { ) }\end{array}$ & \\
\hline 15 & $\begin{array}{l}\text { Dispersion of light by a } \\
\text { prism }\end{array}$ & $\begin{array}{l}\text { Dispersion of light by a } \\
\text { prism (pp. 58-59) }\end{array}$ & \multirow{2}{*}{$\begin{array}{l}\text { Dispersion of light, } \\
\text { Applications of total } \\
\text { internal } \\
\text { reflection by a prism (2) }\end{array}$} \\
\hline 16 & $\begin{array}{l}\text { Applications of total } \\
\text { internal reflection of light } \\
\text { by a prism }\end{array}$ & $\begin{array}{l}\text { Applications of total } \\
\text { internal reflection of } \\
\text { light by a prism (pp. 59- } \\
60 \text { ) } \\
\text { Use of prisms in } \\
\text { periscopes (pp. 60-61) }\end{array}$ & \\
\hline 17 & $\begin{array}{l}\text { Problem-solving related to } \\
\text { combined thin lenses and } \\
\text { refraction of light }\end{array}$ & Exercises (pp. 62-68) & $\begin{array}{l}\text { Problem-solving related } \\
\text { to combined thin lenses } \\
\text { and } \\
\text { refraction of light (2) }\end{array}$ \\
\hline
\end{tabular}

The unit of thin lenses comprises 17 topics (REB, 2015a, pp. 23-24) to be completed in 24 periods (one period is 40 minutes). Six topics are related to prism - refraction through prisms, terms associated with the refraction of passing through a prism, deviation of light rays by a glass prism, angle of minimum deviation and the 
determination of the refractive index of a prism, dispersion of light by a prism, and applications of total internal reflection of light by a prism.

Table C2 is the sample lesson plan. This is one LP (Table D1) from sampled 32 LPs. It is the one we referred to during preparing the model physics lesson plan (Table C3).

\section{Table C2: Sample LP}

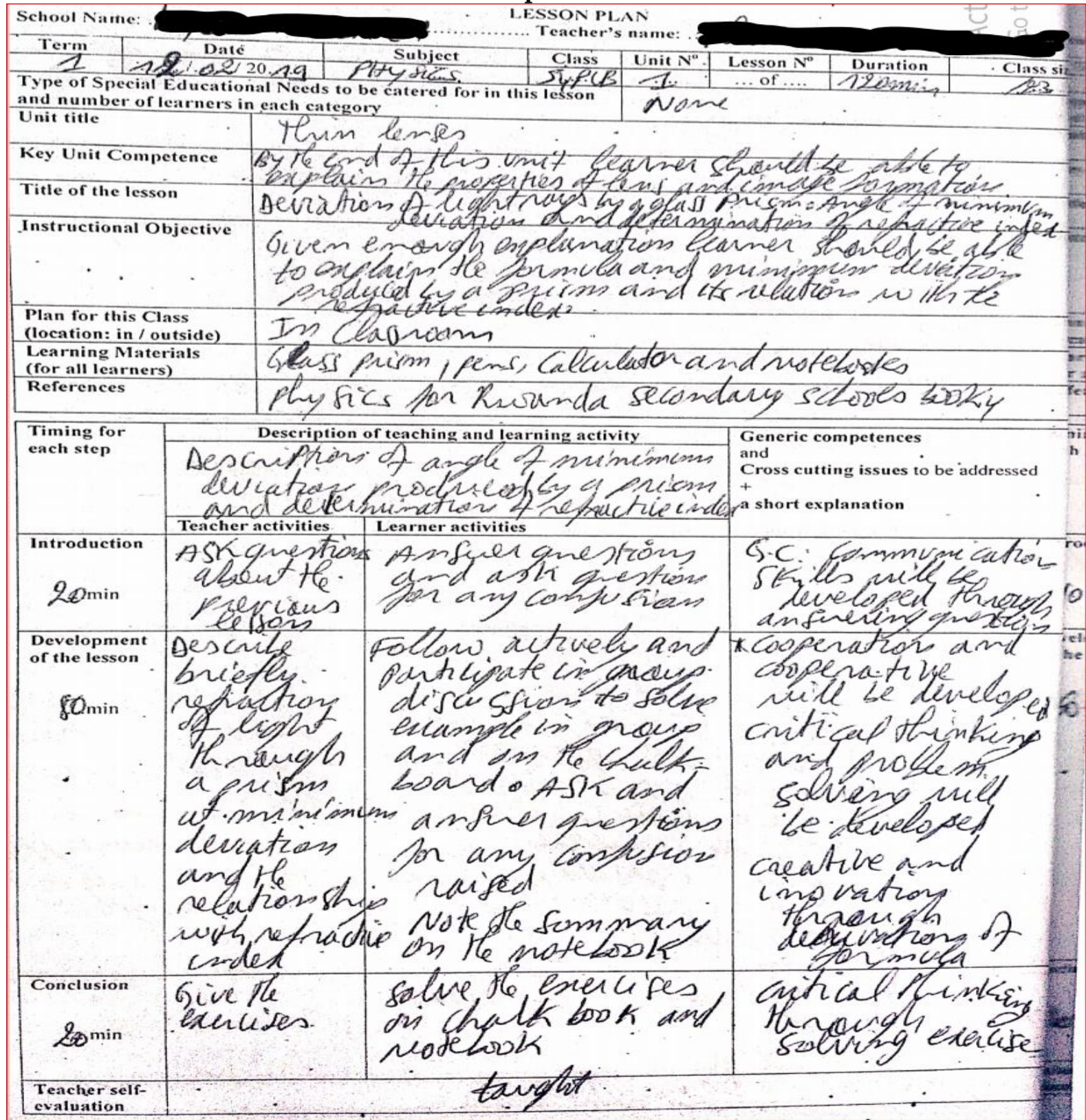


Note that the lesson plan we drafted is in the format recommended by the REB. We followed their format, but the content was prepared as an example by ourselves to support the LP under Table C2. So, the mistakes or misinformation that may be brought by our content has no way to be attributed to REB or teacher's LP under Table C2. However, we have validated it to the extent it can serve as a model lesson plan to be consulted by any physics teacher for proper planning. Our LP draft was shared with seven people. These were three URCE assistant physics lecturers (among them one teach teaching methods in addition to physics), one consultant who worked for the SIIQS3 project, and three master students at ACEITLMS/URCE who were physics teachers in secondary schools before 2019. After receiving their validation reports (five reports from five people who responded to our request), we have considered their suggestions and input to enrich our LP draft and provide the current model LP (see Table C3).

\footnotetext{
${ }^{3}$ SIIQS refers to the Project for Supporting Institutionalizing and Improving the Quality of SBI (School-Based In-service Teacher Training) Activity. This project was piloted jointly by Rwanda Education Board (REB) and Japan International Cooperation Agency (JICA) from 2017 to 2019
} 
Table C3: Model lesson plan

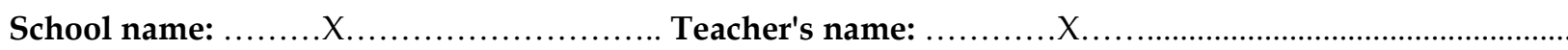

\begin{tabular}{|c|c|c|c|c|c|c|c|}
\hline Term & Date & Subject & Class & $\begin{array}{l}\text { Unit } \\
\text { No }\end{array}$ & Lesson No & Duration & Class size \\
\hline I & $\begin{array}{c}12 \text { February } \\
2019\end{array}$ & Physics & $\begin{array}{c}\text { Senior } 4 \\
\text { PCB }\end{array}$ & 1 & 10 of 12 & 80 Minutes & 45 \\
\hline \multicolumn{4}{|c|}{$\begin{array}{l}\text { Type of Special Educational Needs to be catered for in this } \\
\text { lesson and number of learners in each category }\end{array}$} & \multicolumn{4}{|c|}{$\begin{array}{l}\text { One student has visual impairment (short-sightedness) while ten students are } \\
\text { slow to understand physics concepts together with the other seven students fear } \\
\text { mathematical formulae }\end{array}$} \\
\hline Unit title & \multicolumn{7}{|c|}{ ( } \\
\hline Key Unit Competence & \multicolumn{7}{|c|}{ By the end of this unit, the learner should be able to explain the properties of lenses and image formation by lenses } \\
\hline Title of the lesson & \multicolumn{7}{|c|}{$\begin{array}{l}\text { Determination of refractive index of the Prism; Deviation of light by the Prism, Minimum deviation, Determination of } \\
\text { refractive index of a material of a glass prism using minimum deviation }\end{array}$} \\
\hline Instructional Objective & \multicolumn{7}{|c|}{$\begin{array}{l}\text { Through experiments using materials such as glass prism of refracting angle } 60^{\circ} \text {, a sheet of paper, soft board, pins, and } \\
\text { pencils, ruler, and protractor; through a series of exercises; learners should be able to: } \\
\text { - determine the refractive index of a material of a prism correctly. } \\
\text { - measure the angle of deviation d accurately } \\
\text { - } \text { - clot a graph of deviation d against the angle of incidence accurately } \\
\text { refractive index } \\
\text { - determine the refractive index of a material of a glass prism using the minimum deviation formula easily. }\end{array}$} \\
\hline $\begin{array}{l}\text { Plan for this Class } \\
\text { (location: in / outside) }\end{array}$ & \multicolumn{7}{|c|}{ This lesson will be conducted inside the classroom } \\
\hline Learning Materials & \multirow{2}{*}{\multicolumn{7}{|c|}{ Glass prism, pins, white papers, soft board, pencils, ruler, protractor, calculators, notebooks }} \\
\hline (for all learners) & & & & & & & \\
\hline
\end{tabular}




\begin{tabular}{|c|c|c|c|}
\hline References & \multicolumn{3}{|c|}{ Physics for Rwandan secondary schools Learner's Book 4, Fountain Publishers } \\
\hline \multirow[t]{3}{*}{ Timing for each step } & \multicolumn{2}{|c|}{ Description of teaching/learning activities } & \\
\hline & \multicolumn{2}{|c|}{$\begin{array}{l}\text { In groups, students perform experiments to determine the refractive index of the prism. The } \\
\text { teacher provides materials, gives instructions, and guides students while students are busy } \\
\text { working towards lesson objectives. }\end{array}$} & \multirow{2}{*}{$\begin{array}{l}\text { Generic competences } \\
\text { and } \\
\text { Cross-cutting issues to } \\
\text { be addressed } \\
+ \\
\text { a short explanation } \\
\text { Teacher's activities }\end{array}$} \\
\hline & Teacher's activities & Learner's activities & \\
\hline $\begin{array}{l}\text { 1. Introduction } \\
\text { (10 min) }\end{array}$ & $\begin{array}{l}\text { Ask questions about the previous lesson: } \\
\text {-Describe a prism as an apparatus that refracts light } \\
\text {-Write and interpret the Snell's law and the angle of } \\
\text { the prism } \\
\text { Guide students in answering questions and } \\
\text { clarifying for better conceptual understanding. } \\
\text { Identify students with poor understanding (slow } \\
\text { learners). Make sure everyone understands before } \\
\text { the next lesson; otherwise, consider them in the } \\
\text { next lesson. } \\
\text { Make sure students with short-sightedness are } \\
\text { sitting in front. }\end{array}$ & $\begin{array}{l}\text { Answer to asked questions } \\
\text {-In optics, a prism is a transparent material like } \\
\text { glass or plastic that refracts light. At least two of } \\
\text { the flat surfaces must have an angle of less than } \\
90^{\circ} \text { between them. The exact angle between the } \\
\text { surfaces depends on the application. } \\
\text {-Note that given } i_{1}, r_{1} \text {, and } i_{2}, r_{2} \text { as angles of } \\
\text { incidence and refraction at F and } G \text { as shown and } \\
n \text { is the prism refractive index, then Snell's law } \\
\text { holds. That is; Sin } i_{1}=n \text { sin } r_{1} \text {, and Sin } i_{2}=n \text { sin } \\
r_{2} \text {. } \\
\text { Angle A: This is called the refracting angle or } \\
\text { angle of the prism. It is the angle between the } \\
\text { inclined surfaces of the prism. } r_{1}+r_{2}=A \text {. }\end{array}$ & $\begin{array}{l}\text { GC: Communication } \\
\text { skills will be developed } \\
\text { through answering } \\
\text { questions } \\
\text { CC: Inclusive Education } \\
\text { will be catered for } \\
\text { throughout the lesson }\end{array}$ \\
\hline
\end{tabular}




\begin{tabular}{|c|c|c|c|}
\hline $\begin{array}{l}\text { 2. Development } \\
\text { of the lesson } \\
\text { (65 min) }\end{array}$ & $\begin{array}{l}\text { Form groups (seven groups of 6-7 students) by } \\
\text { considering a mixture of both boys and girls, } \\
\text { smart and slow learners. } \\
\text { Give instructions on what they are going to do } \\
\text { (experiment). } \\
\text { Assign different experiment tasks to different } \\
\text { groups of students in order to keep time and call } \\
\text { attention. } \\
\text { Ask students to follow the procedures and } \\
\text { record findings in their notebooks. Remind them } \\
\text { that they have different tasks and be ready to teach } \\
\text { their colleagues what every group did and found. } \\
\text { Guide each group to achieve expected results } \\
\text { and monitor the experiment procedure. } \\
\text { Note down the difficulties that groups face and } \\
\text { individuals' capabilities to learn which groups } \\
\text { will present in the next session. }\end{array}$ & $\begin{array}{l}\text { Follow instructions and form groups as } \\
\text { requested. } \\
\text { Participate actively in groups by helping } \\
\text { each other to perform experiments and } \\
\text { following the procedure referred to in } \\
\text { textbooks. } \\
\text { Experiment } 1 \text { (to be done by group 1, 4, and } \\
7 \text { ) } \\
\text { Determination of refractive index of a material } \\
\text { of a prism (activity } 32, p \text {. } 57 \text { student's book) } \\
\text { Experiment } 2 \text { (to be done by group } 2 \text { and } 5 \text { ) } \\
\text { Deviation of light by the prism (activity } 30, p \text {. } \\
\text { 50 student's book) } \\
\text { Experiment } 3 \text { (to be done by group } 3 \text { and } 6 \text { ) } \\
\text { Minimum deviation (activity } 31, p .51 \text { student's } \\
\text { book) } \\
\text { Ask for guidance and record data on the } \\
\text { notebook. }\end{array}$ & $\begin{array}{l}\text { GC: Cooperation will be } \\
\text { developed through } \\
\text { working together } \\
\text { performing experiment } \\
\text { GC: Interpersonal } \\
\text { relations and life skills } \\
\text { will be developed by } \\
\text { supporting each other } \\
\text { perform experiment }\end{array}$ \\
\hline
\end{tabular}




\begin{tabular}{|c|c|c|c|}
\hline $\begin{array}{l}2.2 \text { presentation learners' } \\
\text { findings production } \\
(15 \mathrm{~min})\end{array}$ & $\begin{array}{l}\text { Make sure students respect the time and spare } \\
\text { time for them to share their findings. } \\
\text { Depending on the teacher's notes (during } \\
\text { monitoring experimentation), assign one of the } \\
\text { groups who performed experiment } 1 \text { to } \\
\text { present on what they did and found. It is } \\
\text { better to allow the group that got difficulties } \\
\text { in order to raise discussion in the next session. } \\
\text { Let the group that faced more challenges take } \\
\text { the first floor to present and turn those } \\
\text { challenges into an opportunity to better } \\
\text { understand concepts. }\end{array}$ & $\begin{array}{l}\text { Group } 1 \text { or } 4 \text { or } 7 \text { shares what they did } \\
\text { related to experiment } 1 \text { in front of the } \\
\text { class } \\
\text { Group } 2 \text { or } 5 \text { shares what they did } \\
\text { related to experiment } 2 \text { in front of the } \\
\text { class } \\
\text { Group } 3 \text { or } 6 \text { shares what they did } \\
\text { related to experiment } 3 \text { in front of the } \\
\text { class } \\
\text { Other students follow actively and } \\
\text { participate in discussions by asking for } \\
\text { clarification. }\end{array}$ & $\begin{array}{l}\text { GC: Communication skills } \\
\text { will be developed during } \\
\text { students presentation } \\
\text { GC: Creativity and } \\
\text { innovation will be } \\
\text { developed through } \\
\text { generating the ideas in } \\
\text { case of being challenged }\end{array}$ \\
\hline $\begin{array}{l}2.3 \text { exploitation findings } \\
\text { production }(20 \mathrm{~min})\end{array}$ & $\begin{array}{l}\text { Start the discussion by motivating the rest of } \\
\text { the class to challenge the presenters. } \\
\text { Guide discussion of students. } \\
\text { Give an activity for all the groups. This will } \\
\text { make students use what they found in the } \\
\text { experimentation. } \\
\text { Activity: Determination of refractive index of a } \\
\text { material of a glass prism using minimum deviation } \\
\text { by working out exercises as group work. }\end{array}$ & $\begin{array}{l}\text { Ask clarification, and others respond } \\
\text { Discuss the presented findings. } \\
\text { Derive the relation between minimum } \\
\text { deviation and the refractive index of the } \\
\text { material: } \\
n=\operatorname{Sin} \frac{(\operatorname{Dmin}+A)}{2} / \operatorname{Sin} \frac{A}{2}\end{array}$ & $\begin{array}{l}\text { GC: Cooperation and } \\
\text { Interpersonal relations } \\
\text { and life skills will be } \\
\begin{array}{l}\text { developed through } \\
\text { discussion and } \\
\text { challenging each other }\end{array} \\
\text { GC: Critical thinking and } \\
\text { problem solving will be } \\
\text { developed } \\
\text { through the derivation of } \\
\text { formula and solving } \\
\text { exercises }\end{array}$ \\
\hline
\end{tabular}




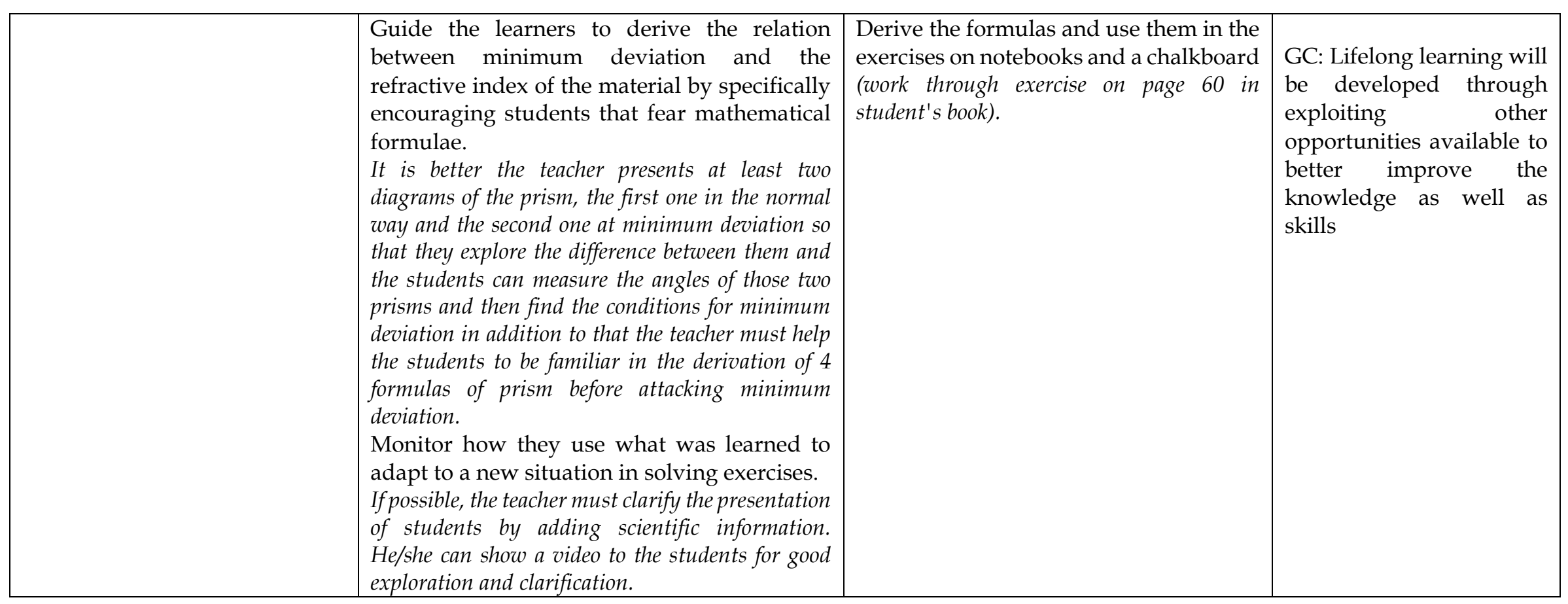




\begin{tabular}{|c|c|c|c|}
\hline $\begin{array}{l}2.4 \text { conclusion/ } \\
(10 \mathrm{~min})\end{array}$ & $\begin{array}{l}\text { Call for volunteer students to sum up what } \\
\text { was learned. } \\
\text { A better way is to call some students whom you } \\
\text { found had some challenges. } \\
\text { Another way is to ask one student from groups that } \\
\text { did, let say, experiment } 1 \text { to talk about what he/she } \\
\text { learned from the work done by students who did } \\
\text { experiment } 2 \text { or } 3 \text {. } \\
\text { Another better way is to ask everyone to write a } \\
\text { summary of today's lesson. } \\
\text { Help students contextual and appreciate the } \\
\text { competences gained and skills got in today's } \\
\text { lesson. } \\
\text { Motivate learners to record notes. }\end{array}$ & $\begin{array}{l}\text { Groups evaluate each other } \\
\text { Students share what they learned new in } \\
\text { the lesson } \\
\text { Propose what to do for a better } \\
\text { understanding. } \\
\text { Share the importance of today's lesson. } \\
\text { Share how to apply what they learned in } \\
\text { everyday life. } \\
\text { Record notes on the individual } \\
\text { notebook. }\end{array}$ & $\begin{array}{l}\text { GC: Interpersonal } \\
\text { relations and life skills } \\
\text { will be developed through } \\
\text { challenging each other; } \\
\text { therefore, this will } \\
\text { promote the Development } \\
\text { of the higher-order } \\
\text { thinking skills } \\
\text { GC: Lifelong learning will } \\
\text { be developed via } \\
\text { contextualizing the } \\
\text { learned concepts }\end{array}$ \\
\hline $\begin{array}{l}\text { 3. assessment /homework } \\
(5 \mathrm{~min})\end{array}$ & Assign homework as an individual work. & $\begin{array}{l}\text { Record the homework in an individual } \\
\text { notebook. }\end{array}$ & \\
\hline Teacher self-evaluation & \multicolumn{3}{|c|}{$\begin{array}{l}\text { The lesson was well done; about ten students still have difficulties in mathematical formulae; before the next lesson } \\
\text { (lesson 11: Dispersion of light), I will make corrections of homework by engaging them during the first } 15 \text { minutes. }\end{array}$} \\
\hline
\end{tabular}

